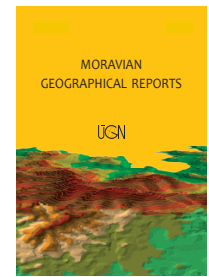

MORAVIAN GEOGRAPHICAL REPORTS

\title{
Comparison of the current state of non-forest woody vegetation in two contrasted case study areas in Central Europe
}

\author{
Katarína DEMKOVÁ ${ }^{\text {** }}$ Zdeněk LIPSKÝ ${ }^{b}$
}

\begin{abstract}
Non-forest woody vegetation (NFWV), as a part of green infrastructure, has gained a great deal of attention in recent years. Despite its importance in many productive and non-productive functions, an inventory (collection of quantitative and qualitative data) on a national or even on a local level is not available in many European countries. The main aim of this study is to carry out a comparison of two study areas (lowland and upland) from the perspective of the current state of NFWV. We investigate qualitative attributes of NFWV, its relation to environmental conditions and its spatial pattern. After manual vectorization of orthophotos, qualitative data were collected in the field. Using statistical and landscape-ecological methods, the relation between NFWV and environmental conditions, as well as its spatial pattern were assessed. Substantial differences in character and in the spatial pattern of NFWV were identified between the study areas. NFWV in the upland area has a higher proportion (2.6\%) than in lowland study area (1.5\%), and it also has a more heterogeneous spatial structure. Statistical analysis points to a significant relation between the NFWV and land cover types in both study areas. A significant relation between NFWV and soil types was identified only in the upland area, however, while an association with potential natural vegetation was found in the lowland study area.
\end{abstract}

Key words: non-forest woody vegetation, landscape metrics, spatial analysis, inventory, Central Europe

Article history: Received 10 March 2016; Accepted 3 January 2017; Published 31 March 2017

\section{Introduction}

Trees growing outside forests have received increased attention worldwide in recent years. They grow in diverse environments around the world, but the highest importance is ascribed to those areas where forests have never been recorded, or conversely, where they have disappeared. Although forests still remain a traditional topic of research and public interest, trees outside forests have emerged as a significant research issue for two main reasons. First, they have ecological impacts far beyond the proportion of land they occupy (Manning et al., 2006; Fischer et al., 2010). Second, little is known about their dynamics. In general, their areal extent has been rapidly changing worldwide since the 1950s (Bélouard and Coulon, 2002; Hidalgo and Kleinn, 2002; Manning et al., 2009). The main drivers of land use changes are mechanisation and intensification of agriculture on the one hand, and extensification and land abandonment on the other (McDonald et al., 2000; Plieninger et al., 2006; Kümmerle et al., 2006).
Trees are crucial to economic and environmental, as well as human, well-being (Editorial, 2000), but their inventory (collection of quantitative and qualitative data) is missing. The term trees outside forests, according to FAO (2001), includes all trees growing on land not defined as forest and other wooded land with an area less than 0.5 ha. It also comprises trees in urban areas, including parks and gardens, as well as permanent tree crops such as fruit trees and orchards.

This study is focused on non-forest woody vegetation (NFWV) with an area of less than 0.3 ha, which includes stable woody vegetation that is not a forest, nor an agricultural crop or a part of any built-up area in the landscape (Bulír and Škorpík, 1987; Mareček, 2005). This term has become very popular in many research fields such as landscape planning, landscape architecture, landscape ecology or biology. NFWV is an important feature of the rural landscape because it affects not only the water infiltration and retention but it also provides microclimate, soil and biodiversity protection. It plays a significant role

\footnotetext{
${ }^{a}$ Silva Tarouca Research Institute for Landscape and Ornamental Gardening, Publ. Res. Inst., Průhonice, Czech Republic (*corresponding author: K. Demková, e-mail: demkova@vukoz.cz)

${ }^{\mathrm{b}}$ Department of Physical Geography and Geoecology, Faculty of Science, Charles University in Prague, Czech Republic
} 
for organisms living in agricultural landscapes because it provides food, refuge and serves as a corridor or natural source for seeds (regeneration) (McCollin et al., 2000; Manning et al., 2006). It often forms a basic element of an ecological network as an essential part of the green infrastructure. NFWV supplies people with wood, flowers, fruits, but also serves as shelter, protection against wind and erosion or as demarcation of property boundaries (Harvey and Harber, 1999; Baudry et al., 2000; Mojsej and Petrovič, 2013). Moreover, it contributes to the scenic beauty of landscape and has recreational and educational functions (Hunziker, 1995; Špulerová, 2006).

Recently, many studies have investigated scattered trees, hedgerows and other types of NFWV. Most of them have focused on spatiotemporal changes in the distribution and composition (Burel and Baudry, 1990; Kristensen and Caspersen, 2002; Plieninger et al., 2012; Demková and Lipský, 2015; Skaloš et al., 2015). Other work has aimed at the relation to biodiversity (Burel, 1992; McCollin et al., 2000; Fischer and Lindenmayer, 2002; Ernoult and Alard, 2011), hydrological cycles (Eldridge and Freudenberger, 2005; Ryszkowski and Kedziora, 2007; Chandler and Chappell, 2008), microclimate (Gill et al., 2007; Sánchez et al., 2010), management and conservation (Boffa, 2000; Plieninger et al., 2003; Manning et al., 2006), or landscape memory and heritage (Schama, 1995). Only a few publications refer to methods of inventory and assessment of trees outside forests (Kleinn, 2000; Hidalgo and Kleinn, 2002; Schnell, 2015).

Nonetheless, little is known about the extent and current state of NFWV. Neither monitoring nor an inventory of NFWV on a local or even a national level is supported in the Czech Republic, Slovakia or in most other European countries. An exception is Great Britain where a regular monitoring of hedgerows is provided by the Countryside Survey $(1990,2000,2007)$ on the state level (Barr and Gillespie, 2000). Only a few research studies on a local or regional level in the Czech Republic and Slovakia provide specifically quantitative information (Skaloš and Engstová, 2010; Diviaková, 2010; Demková and Lipský, 2012). The last estimates of NFWV in the Czech Republic and Slovakia were published in the 1980s (Vaníček, 1985; Moldan et al., 1990). After 1989, political and socio-economic changes resulted in dramatic landscape change (urbanisation, landscape abandonment, motorway construction etc.) (e.g. Bičík et al., 2001) that affected the amount and quality of NFWV. The Landscape mapping in 1995 in the Czech Republic was an exception, during which all the landscape features were recorded, including the NFWV throughout the entire country. The NFWV was not processed separately however (Pellantová et al., 1994). Afterwards, the Landscape mapping was replaced by the NATURA 2000 mapping, which focused only on selected landscape segments. Moreover, legislation concerning trees outside forests has changed as well. Evidence on a large scale will enable us to assess the importance of NFWV for landscape functioning and its dynamics. Also Hidalgo and Kleinn (2002) highlighted an inventory providing quantitative and qualitative data about NFWV as crucial for developing management options to help sustain tree cover in general.

Despite many studies concerning different aspects of NFWV, there are still questions that have not been addressed until today. What is the relation between NFWV and natural conditions? Does it depend on any special relief attribute, soil type, degree of nature conservation, etc.? What is the current state of riparian vegetation, alleys, solitary trees, and groves?

The main aim of this study is to assess the current state of NFWV in two study areas, the Kutnohorsko Region (Czech Republic) and the White Carpathians (Slovakia), representing distinct landscape types (lowland and upland area). More specific aims are to investigate the differences between these two regions with respect to:

a. the qualitative attributes of NFWV (shape, formation, crown cover, and habitat type);

b. relation of NFWV to environmental conditions (soil, land cover and potential natural vegetation types); and

c. the spatial pattern of NFWV.

We expect differences in the qualitative attributes of NFWV because the study areas are distinct in natural and socioeconomic conditions, and in spatial pattern as well because of different land use and history. We expect a higher proportion and a more variable spatial structure of NFWV in the upland region because of variable relief and extensive land use.

\section{Materials and methods}

\subsection{Study areas}

Two distinct landscape types were chosen as study areas a lowland area of the Kutnohorsko Region (KH), Czech Republic, and an upland area of the White Carpathians (WC), Slovakia (see Fig. 1). In recent years, detailed research projects have been carried in these study areas (e.g., Lipský et al., 2011; Skaloš et al., 2011; Demková, 2011). Moreover, spatiotemporal changes in the distribution and composition of NFWV after 1950 were investigated in both study areas (Demková and Lipský, 2013, 2015).

The flat relief of the KH study area is formed by the wide alluvial plains of the rivers. Slopes of the Železné hory Mts. extend over the northeastern edge of the study area (for further information see Tab. 1). A mosaic of soil types has developed in the lowland depending on substrate. Fluvisols and cambisols predominate, but also chernozems and rendzic leptosols are represented in the area (Tab. 1). The soil mosaic closely corresponds to the distribution of potential natural vegetation, in which alluvial softwood and hardwood forests in the alluvial plains prevail (UlmetoQuercetum, Pruneto-Fraxinetum). The central part of the study area is covered by oak-hornbeam woodland (Hercynian Melampyro nemorosi-Carpinetum) with patches of pine-oak woodland (Pineto-Quercetum) on sandy substrate. Silverfiroak (Abieto-Quercetum) and woodrush-oak (Luzulo albidaeQuercetum) woodland cover the slopes of the Železné hory Mts. (Neuhäuslová, 1998).

At present, an intensively farmed landscape with a dominant share of arable land prevails (Tab. 1). Most of the study area has a specific landscape character, however, with a diverse landscape structure due to a higher proportion of forest, as well as aesthetically motivated landscape formations around the Kačina and Žehušice castles founded in the $18^{\text {th }}$ and $19^{\text {th }}$ centuries (Lipský et al., 2011). Subsequently, the Landscape Conservation Area Žehušicko was declared open in 1996 in the southern and central part of the study area.

The WC study area is located in the upland terrain (for further information, see Tab. 1). Among soil types cambisols predominate, followed by regosols and rendzic leptosols 


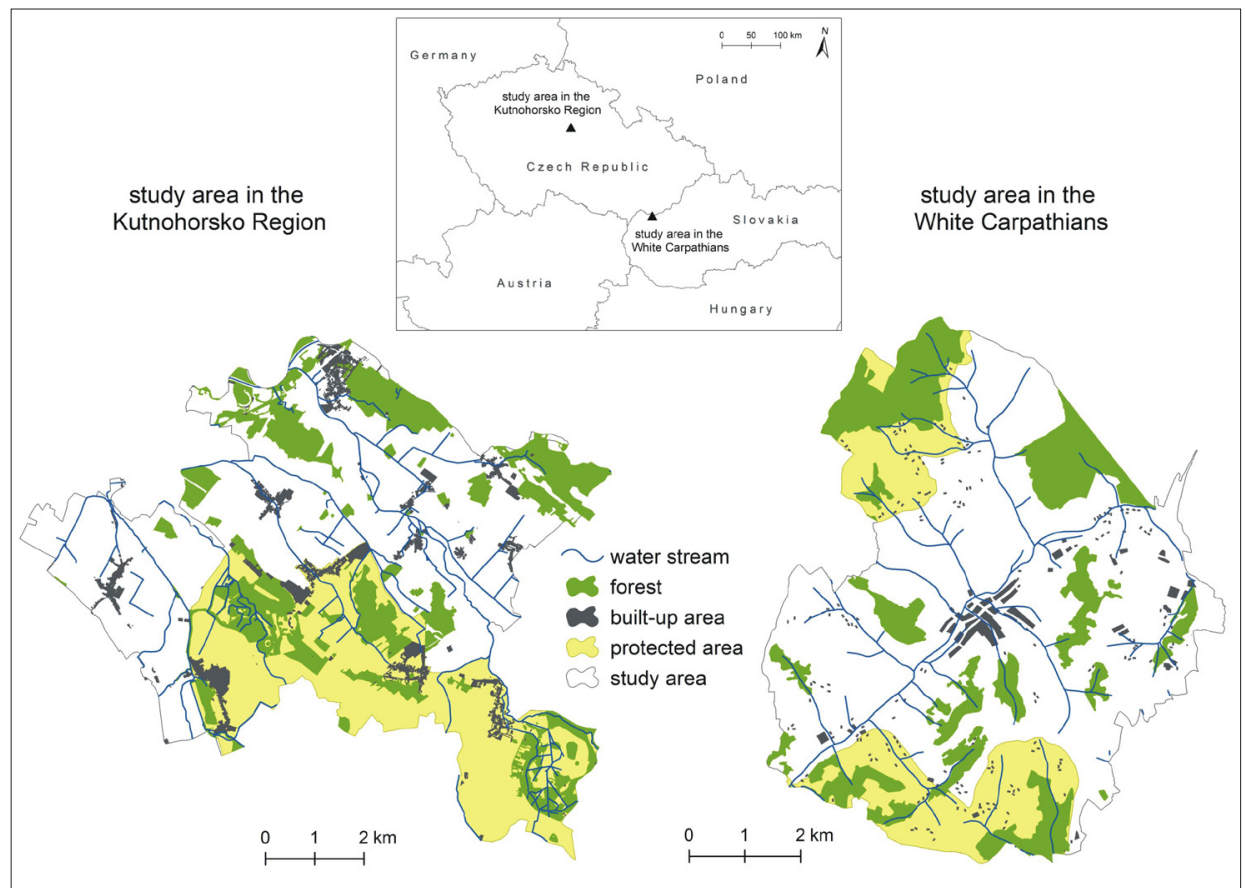

Fig. 1: Location of the study areas Source: authors' elaboration

\begin{tabular}{|c|c|c|}
\hline & KH & WC \\
\hline Geographical coordinates & $49.9852850 \mathrm{~N}, 15.3281789 \mathrm{E}$ & $48.7993900 \mathrm{~N}, 17.4691500 \mathrm{E}$ \\
\hline Area & $60.5 \mathrm{~km}^{2}$ & $51.5 \mathrm{~km}^{2}$ \\
\hline Altitude & 200-320 m a.s.l. & $250-610 \mathrm{~m}$ a.s.l. \\
\hline \multirow[t]{6}{*}{ Soil types* } & Cambisols (20.3\%) & Cambisols (55.1\%) \\
\hline & Fluvisols (42.0\%) & Regosols $(10.7 \%)$ \\
\hline & Chernozems $(12.7 \%)$ & Rendzic leptosols (7.2\%) \\
\hline & Rendzic leptosols (3.2\%) & Phaeozems $(3.0 \%)$ \\
\hline & Kastanozems (1.0\%) & Fluvisols $(0.2 \%)$ \\
\hline & Forest land and urban area (20.8\%) & Forest land and urban area (23.8\%) \\
\hline \multirow[t]{7}{*}{ Land cover** } & Arable land $(65.2 \%)$ & Arable land $(40.5 \%)$ \\
\hline & Pastures $(2.0 \%)$ & Permanent crops $(0.5 \%)$ \\
\hline & Woodland $(19.0 \%)$ & Pastures (19.7\%) \\
\hline & $\begin{array}{l}\text { Landscape principally occupied by agriculture } \\
\text { with significant areas of natural vegetation } \\
(6.8 \%)\end{array}$ & $\begin{array}{l}\text { Landscape principally occupied by agriculture } \\
\text { with significant areas of natural vegetation } \\
(14.3 \%)\end{array}$ \\
\hline & Sport and leisure facilities (1.0\%) & Complex cultivation pattern $(0.7 \%)$ \\
\hline & Urban area $(6.0 \%)$ & Woodland $(22.0 \%)$ \\
\hline & & Urban area $(2.3 \%)$ \\
\hline \multirow[t]{5}{*}{ Potential natural vegetation $* * * *$} & Ulmeto-Quercetum (6.4\%) & Alnion glutinosae (11.9\%) \\
\hline & Pruneto-Fraxinetum $(48.2 \%)$ & Carpathian Carici pilosae-Carpinetum (69.5\%) \\
\hline & $\begin{array}{l}\text { Hercynian Melampyro nemorosi-Carpinetum } \\
(31.6 \%)\end{array}$ & Fagetum $(16.1 \%)$ \\
\hline & Pineto-Quercetum (5.1\%) & Abieto-Fagetum (2.5\%) \\
\hline & $\begin{array}{l}\text { Abieto-Quercetum and Luzulo albidae- } \\
\text { Quercetum }(8.7 \%)\end{array}$ & \\
\hline $\begin{array}{l}\text { Nature and landscape } \\
\text { conservation }\end{array}$ & $\begin{array}{l}\text { Landscape conservation area Žehušicko } \\
(35.5 \%)\end{array}$ & $\begin{array}{l}\text { Protected landscape area White Carpathians } \\
(24.5 \%)\end{array}$ \\
\hline
\end{tabular}

Tab. 1: Basic characteristics of the study areas

Source: authors' compilation

Notes: KH - Kutnohorsko Region, WC-White Carpathians; * KH, WC: Soil maps; ** KH, WC: CORINE Land Cover data (2006); *** KH: Neuhäuslová (1998), WC: Maglocký (2002) 
(Tab. 1). Phaeozems cover narrow alluvial plains. Water streams are accompanied by submontane and montane alder floodplain forests (Alnion glutinosae). Carpathian oakhornbeam woodland (Carpathian Carici pilosae-Carpinetum) covers the majority of the study area except for the highest parts where submontane beech (Fagetum) and fir-beech (Abieto-Fagetum) forests interfere (Maglocký, 2002).

A mosaic of fields, grasslands, orchards and forest (Tab. 1) was formed as a consequence of forest-agricultural activities of the past centuries and the dispersed type of settlement called "crofts", a typical feature of the White Carpathians. Although the intensification of agriculture has affected the upland region as well, the share of arable land has been continuously decreasing in favour of permanent grasslands. Due to high social and cultural as well as natural diversity, the Protected Landscape Area White Carpathians was declared in 1979.

\subsection{Data sources}

Data about the area of NFWV were collected by manual vectorisation of aerial images and orthophotos. All images were transformed into the S-JTSK coordinate system. NFWV in the study area KH was digitised from the 2010 orthophotos available from the Czech Environmental Information Agency (ground resolution $0.5 \mathrm{~m}$ ), and in the WC study area from the 2006 aerial images obtained from the Topographical Institution of the Slovak Republic (aerial images were orthorectified with the final pixel resolution of $0.476 \mathrm{~m}$ ).

Digitisation of NFWV proceeded according to spatial criteria (Bulíř and Škorpík, 1987; Sláviková, 1984; Supuka et al., 1999) in ArcMap 10.0 (ESRI Inc., 2010):

- Patch features - groups of trees and shrubs with a maximum area of 0.3 ha (small woods, groves, vegetation on marshland, on abandoned lands or localities unsuitable for any economic use);

- Linear features - one or more lines of woody vegetation with a minimum length of $30 \mathrm{~m}$, a maximum width of $30 \mathrm{~m}$, but up to $30 \%$ of the length (alleys, riparian vegetation, linear vegetation along railways, on balks, etc.); and

- Point features - one to three individual trees or shrubs.

The area of NFWV was set down as a projection of the tree or shrub crown. The length of linear features was measured along the centerline of the element. The data were collected only for non-forest areas and outside urban localities.

The present state of NFWV was verified and mapped in the field during the growing seasons of 2010 and 2011 in order to collect qualitative information on its character. The following attributes were described:

- Formation - tree, shrub or mixed (according to Sláviková, 1987; Kolařík et al., 2003);

- Crown cover - continuous, gapped, solitaire (according to Sláviková, 1987; Kolařík et al., 2003); and

- Habitat type - water streams and water areas, roads and railways, wet sites and springs, erosive depressions, balks, plot boundaries, unused, abandoned sites, technical constructions, secular or religious monuments, designed landscape (for more information see Demková and Lipský, 2012, 2015).

After that, we analysed the relation of NFWV to the following environmental conditions:
- soil types derived from the Soil maps 1:5,000 (Soil Science and Conservation Research Institute, Slovak Republic; Research Institute for Soil and Water Conservation, Czech Republic) and named according to IUSS Working Group WRB (2006) nomenclature;

- land cover types derived from the CORINE Land Cover data 2006 (Slovak Environment Agency 1: 50,000; Czech Environmental Information Agency $1: 100,000$ );

- potential natural vegetation types derived from the Maps of potential natural vegetation $1: 500,000$ (Maglocký, 2002; Neuhäuslová, 1998); and

- nature and landscape conservation (protected landscape area, landscape conservation area).

\subsection{Data analysis}

NFWV in the study areas was compared based on its attributes (shape, formation, crown cover, habitat type). For the purpose of comparison, the area of each class was divided by the area of the study site $\left(\mathrm{m}^{2} / \mathrm{km}^{2}\right)$.

The relationship between the areal extent of NFWV and environmental conditions (categorical explanatory variables) was explored by the non-parametric Kruskal-Wallis one-way analysis of variance at a confidence level $p=0.05$. Statistical analyses were performed using STATISTICA (StatSoft Inc., 2009).

In order to evaluate differences in spatial pattern and internal interactions of individual NFWV units between study areas, basic landscape metrics (Tab. 2) were measured using the ArcGIS extensions Patch Analyst 5.1 (Rempel et al., 2012) and V-LATE 2.0 beta (Lang and Tiede, 2003). Such metrics have been widely used in landscape ecology as indicators of landscape heterogeneity, connectivity or fragmentation (Botequilha-Leităo et al., 2006; Skaloš and Engstová, 2010; Mallinis et al., 2011).

\section{Results}

\subsection{Current state of non-forest woody vegetation in the study areas}

The proportion of NFWV in the KH study area is 1.5\%, while in WC $2.6 \%$ (Tab. 3). All three shape classes (linear, patch, point) have higher proportion in the study area WC (Fig. 2). Linear features have the highest proportion of the NFWV in both study areas (85\% in WC and $88 \%$ in $\mathrm{KH}$ ).

In WC, NFWV is connected especially with agrarian balks, erosive depressions and plot boundaries, which have only low representation in $\mathrm{KH}$. A more balanced representation in both study areas is seen for NFWV along roads, water streams and water areas or on wet sites. In $\mathrm{KH}$, it is also related to designed landscapes, and to secular and religious monuments with very low proportions, but they are not presented at all in the WC study area (Fig. 2).

From the aspect of formation (Fig. 2), mixed vegetation (trees and shrubs together) dominates in both study areas (mainly in linear and patch features). NFWV in KH has a higher proportion of tree formation (particularly in point and patch features). On the contrary, shrub formations have higher representation in WC. Continuous crown cover dominates in WC, while gapped NFWV is slightly more abundant in $\mathrm{KH}$. In particular, linear features along roads, water streams and drainage channels in $\mathrm{KH}$ are not continuous. The solitary NFWV has only very small representation in both study areas (Fig. 2). 


\begin{tabular}{|c|c|c|c|}
\hline Metrics & Units & Description & Function \\
\hline Class area proportion & $\%$ & $\begin{array}{l}\text { The proportion of the class area in the } \\
\text { study area }\end{array}$ & Fragmentation \\
\hline Patch density & $\mathrm{No} / \mathrm{km}^{2}$ & $\begin{array}{l}\text { The number of polygons in the class per } \\
\text { square km (total area of the study area) }\end{array}$ & Landscape heterogeneity, fragmentation \\
\hline Mean patch size & $\mathrm{m}^{2}$ & The average area of all polygons in the class & Habitat size, fragmentation \\
\hline Edge density & $\mathrm{m} / \mathrm{ha}$ & $\begin{array}{l}\text { The total edge of all edge segments in the } \\
\text { class to the total area of the study area }\end{array}$ & Ecotones, edge effect \\
\hline Mean nearest neighbour distance & - & $\begin{array}{l}\text { The average of distances from a patch } \\
\text { to the nearest neighbouring patch of } \\
\text { the same class (based on edge-to-edge } \\
\text { distance) for each class }\end{array}$ & Degree of isolation, connectivity \\
\hline Shannon's diversity index & - & $\begin{array}{l}\text { The sum, across all classes, of the } \\
\text { proportional abundance of each class } \\
\text { multiplied by that proportion }\end{array}$ & Landscape heterogeneity \\
\hline Relative length of linear vegetation & $\mathrm{km} / \mathrm{km}^{2}$ & $\begin{array}{l}\text { The total length of all linear features to } \\
\text { the total area of the study area }\end{array}$ & Connectivity \\
\hline
\end{tabular}

Tab. 2:Landscape metrics used for spatial pattern analysis

Source: authors' compilation (after McGarigal et al., 2002; Botequilha-Leităo et al., 2006; Skaloš and Engstová, 2010)

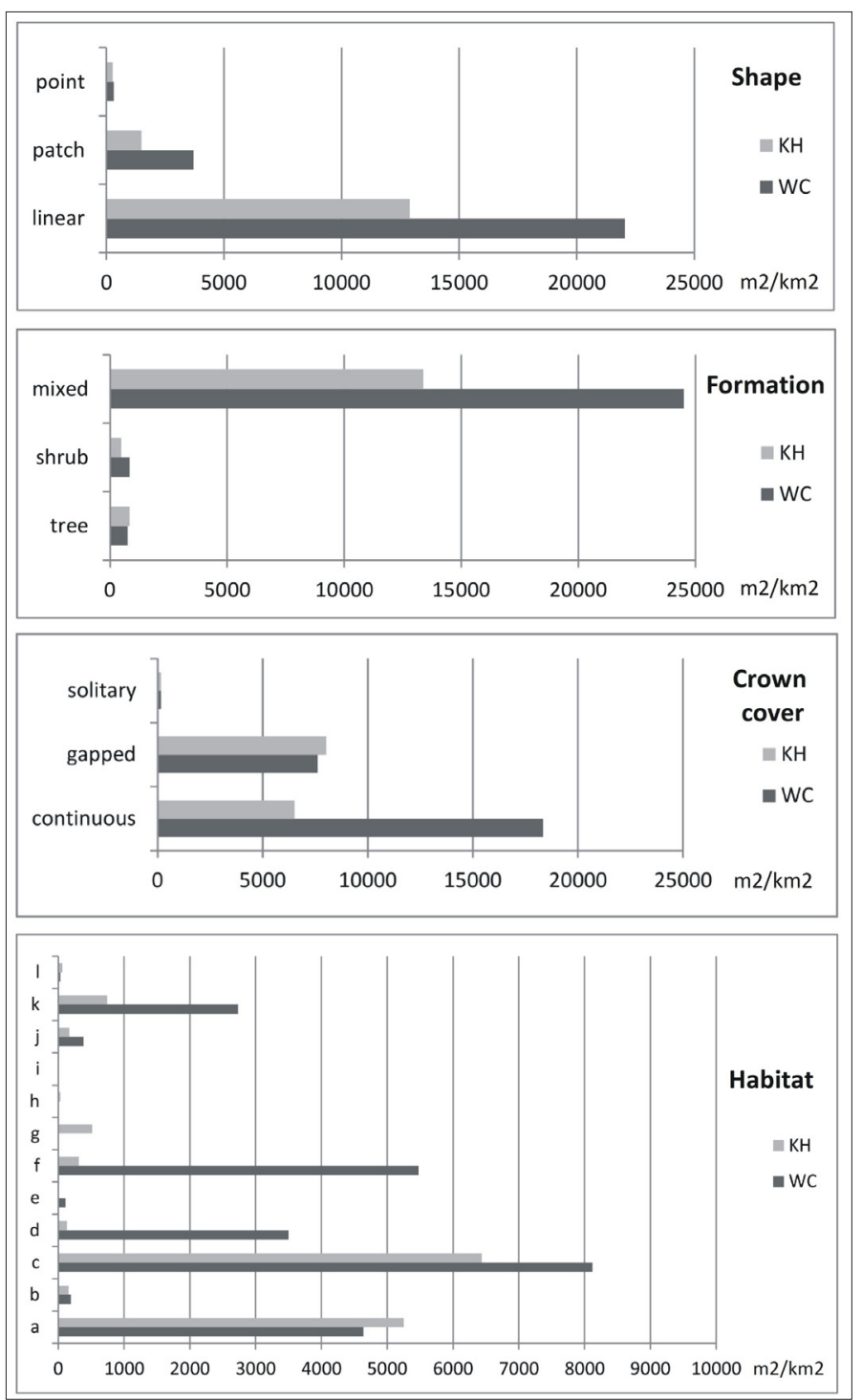

Fig. 2: Areal representation of non-forest woody vegetation in the White Carpathians and the Kutnohorsko Region according to mapped attributes (in $\mathrm{m}^{2} / \mathrm{km}^{2}$ of the study area). Source: authors' calculations

Legend: KH - Kutnohorsko Region, WC - White Carpathians; $a$-roads; $b$-wet sites; $c$ - water streams and water areas; $d$-erosive depressions; $e$-stone balks; $f$-balks; $g$-designed landscape; $h$-religious monuments; $i$ - secular monuments; $j$ - unused places, abandoned; $k$ - plot boundaries; $l$-technical constructions 


\begin{tabular}{|c|c|c|c|c|c|c|c|c|c|c|c|c|}
\hline \multirow[t]{2}{*}{ NFWV } & \multicolumn{2}{|c|}{$\begin{array}{c}\text { Class area } \\
\text { proportion }(\%)\end{array}$} & \multicolumn{2}{|c|}{$\begin{array}{l}\text { Patch density } \\
\left(\mathrm{No} / \mathbf{k m}^{2}\right)\end{array}$} & \multicolumn{2}{|c|}{$\begin{array}{l}\text { Mean patch size } \\
\qquad\left(\mathbf{m}^{2}\right)\end{array}$} & \multicolumn{2}{|c|}{$\begin{array}{l}\text { Edge density } \\
\qquad(\mathrm{m} / \mathrm{ha})\end{array}$} & \multicolumn{2}{|c|}{$\begin{array}{c}\text { Mean nearest } \\
\text { neighbour } \\
\text { distance }\end{array}$} & \multicolumn{2}{|c|}{$\begin{array}{c}\text { Shannon's } \\
\text { diversity index }\end{array}$} \\
\hline & $\mathrm{KH}$ & WC & $\mathrm{KH}$ & $\mathrm{WC}$ & $\mathrm{KH}$ & WC & $\mathrm{KH}$ & WC & $\mathrm{KH}$ & WC & $\mathrm{KH}$ & WC \\
\hline Linear & 1.3 & 2.2 & 7 & 12 & 1,735 & 1,804 & 44 & 39 & 38 & 40 & - & - \\
\hline Patch & 0.2 & 0.4 & 2 & 13 & 722 & 293 & 2 & 8 & 158 & 77 & - & - \\
\hline Point & 0.03 & 0.03 & 6 & 10 & 48 & 32 & 1 & 2 & 113 & 79 & - & - \\
\hline Total & 1.5 & 2.6 & 15 & 35 & 953 & 742 & 47 & 48 & 83 & 65 & 0.42 & 0.48 \\
\hline
\end{tabular}

Tab. 3: Spatial pattern of non-forest woody vegetation in the study areas expressed by landscape metrics (KH Kutnohorsko Region, WC - White Carpathians)

Source: authors' calculations

\subsection{Relation of non-forest woody vegetation to environmental conditions}

The relations between NFWV and environmental conditions vary widely in the study areas. While in WC the distribution of NFWV is significantly affected by soil and land cover types (soil types: $\mathrm{H}(5,1809)=55.659$; $\mathrm{p}<0.0001$; land cover: $\mathrm{H}(3,1809)=13.756 ; \mathrm{p}=0.0033)$, in $\mathrm{KH}$ it is significantly related only to land cover types $(\mathrm{H}(4,928)=9.536 ; \mathrm{p}=0.0490)$. Despite the non-significant relation of NFWV to soil types $(\mathrm{H}(4,928)=2.123$; $\mathrm{p}=0.7131$ ), it is evident that linear vegetation in $\mathrm{KH}$ relates to chernozems, while point and patch features are associated particularly with fluvisols occurring on the alluvial plains. The same relations were determined in WC for phaeozems. On the other hand, the lowest proportion of NFWV is on cambisols in both study areas. In terms of land cover, NFWV has a higher proportion in extensively farmed landscape types, such as land principally occupied by agriculture, with significant areas of natural vegetation and pastures in both study areas. Furthermore, a high proportion was recognized in complex cultivation patterns in $\mathrm{WC}$ and in sport and leisure facilities in $\mathrm{KH}$ (in this case, the park around Kačina castle).

Conversely, the relation between NFWV and potential natural vegetation was detected in WC as non-significant $(\mathrm{H}(4,1809)=8.659 ; \mathrm{p}=0.0702)$, but in $\mathrm{KH}$ as significant $(\mathrm{H}(5,928)=20.052 ; \mathrm{p}=0.0012)$. Among potential natural vegetation types in $\mathrm{KH}$, the highest proportion of NFWV relates to elm-oak woodland (Ulmeto-Quercetum) (especially patch and point NFWV) and bird cherry-ash woodland (Pruneto-Fraxinetum) (mainly linear vegetation in the alluvial plains).

Differences in the relative area of NFWV between the protected and unprotected areas of both study areas are significant in all three NFWV shape types. A higher proportion of patch and point vegetation is found inside the Landscape Conservation Area of Žehušicko in $\mathrm{KH}$, while linear NFWV has a higher proportion outside the protected area. On the contrary, a higher representation of all NFWV shape types is located outside the Protected Landscape Area of the White Carpathians.

\subsection{Spatial pattern of non-forest woody vegetation}

The landscape metrics point to higher heterogeneity in the WC study area, expressed by a higher patch density in all NFWV classes, higher class area proportion for linear and patch vegetation, as well as by slightly higher Shannon's diversity index of NFWV (Tab. 3). Comparing the study areas, substantially higher patch density was detected for patch vegetation in WC. On the contrary, mean patch size of patch vegetation is two and half times higher in KH. Nevertheless, linear and point vegetation has similar mean patch size in both study areas (Tab. 3). The mean nearest neighbour distance index of point and patch vegetation is higher in $\mathrm{KH}$, which corresponds closely with patch density. Both metrics point to a lower connectivity of these classes in $\mathrm{KH}$. On the other hand, linear NFWV shows similar values in both study areas. The relative length of linear vegetation is higher in $\mathrm{KH}\left(2.2 \mathrm{~km} / \mathrm{km}^{2}\right)$ than in WC $\left(1.8 \mathrm{~km} / \mathrm{km}^{2}\right)$. Therefore, the edge density of linear NFWV is higher in KH as well (Tab. 3).

\section{Discussion}

Considerable differences in the current state of NFWV were recognized between the KH and WC study areas. The higher proportion of NFWV in the study area WC (2.6\%) than in $\mathrm{KH}(1.5 \%)$ results from natural conditions that determine land use. $\mathrm{KH}$ represents an intensively farmed landscape where NFWV is still considered to be a barrier or negative feature. This confirms the extent of NFVW just on agricultural land, which is substantially larger in WC (3.4\%) than in KH (2.1\%). According to Machovec (1994), NFWV should cover at least $1.5 \%$ of agricultural land to properly provide environmental functions. The proportion of NFWV in $\mathrm{KH}$ is higher than this limit as a consequence of the alluvial landscape character (riparian vegetation in alluvial plains) and the landscaping activities in the past around Kačina and Žehušice castles (castle parks and game reserves), which were preserved to the present. On the other hand, there are parts with large open fields where NFWV is absent. The distribution of NFWV in this study area is substantially uneven. Therefore it is necessary to fill the gaps and set measures that eliminate wind erosion and increase the retention ability of the landscape.

The current state of NFWV is related to its historical development, which was investigated in previous studies (Demková, Lipský, 2012, 2015). Since the 1950s, NFWV has rapidly decreased in both study sites due to collectivisation and land re-allotment during the communist era. Lack of protection of this vegetation in the latter period led to the removal of a lot of natural features such as NFWV or wet sites, which hindered the intensification of agriculture and increasing building development. Moreover, land abandonment, typical for upland areas, caused overgrowth of non-forested sites with NFWV and their transformation to forest (Plieninger et al., 2006; Kümmerle et al., 2006; Demková, Lipský, 2015). In recent years, a small increase in NFWV has been recognised in the upland study area, particularly due to enlarging existing vegetation (especially linear features). 
As mentioned above, NFWV was not protected during the socialist era, only in cases of special historical, cultural or natural value. Absence of any legislative protection resulted in the decrease of NFWV, as documented by Demková and Lipský $(2012,2015)$. NFWV in general has started to be an integral part of nature conservation as trees outside forests since the $1990 \mathrm{~s}$, which prevented them from unreasonable removal and subsequently contributed to their better current condition. Even so, management measures for their maintenance are still absent. Manning et al. (2009) emphasise that management should be an integral part of conservation objectives and agricultural activities in modified landscapes as well.

Linear vegetation is the dominant shape class of NFWV in both study areas. Its relative length reaches higher values in $\mathrm{KH}$ than in WC even though the area is smaller. Alluvial plains in $\mathrm{KH}$, which comprise about $40 \%$ of the study area, provide appropriate conditions for riparian vegetation. Many linear features, however, do not form continuous cover, especially those along the roads and drainage channels. In WC, continuous linear vegetation dominates particularly along the erosive depressions, plot boundaries and agrarian balks, while it is mostly gapped along the water streams and roads. In this context, we would like to point out the restoration needs of old and absent vegetation in both study areas.

Among the mapped attributes of NFWV, the habitat type of NFWV is partially determined by land use. In both study areas, vegetation along roads, streams and water areas dominates. There are habitat types, however, that can be considered typical for their study area. In KH, NFWV is connected with landscaping activities, while in WC it relates to erosive depressions and agrarian balks, especially stone balks.

The designed landscape around the castles with managed parks in KH has contributed to a higher concentration of tree vegetation in that study area (especially patch and point features), which is still managed (elimination of succession). Conversely, a higher concentration of shrub formation is found in WC where shrubs spread naturally by succession caused by landscape abandonment.

With respect to the relation of NFWV and environmental conditions, the results of this study support some of the conclusions of Sklenička et al. (2009), who also investigated relations between hedgerows and natural conditions. Their results confirm a higher relation of hedgerows to extensively farmed landscape types such as grasslands and a mosaic of fields, grasslands and orchards, which corresponds with our findings. On the other hand, they also noted the dependence of hedgerows on soil fertility, where a higher proportion of NFWV was on less fertile soils. Our results show the opposite. It comes from a high proportion of riparian vegetation in both study areas growing on fertile soil types, such as fluvisols and phaeozems, and other vegetation growing on chernozems.

The assumption that nature and landscape conservation (protected landscape area, landscape conservation area) contributes to a higher concentration of NFWV was not confirmed in both study areas. Only patch and point vegetation have higher proportions in the protected area of the KH study area. This NFWV is a result of the previouslymentioned landscaping activities around the castles and has a specifically aesthetic function. Linear vegetation is more concentrated outside of the protected area because a larger area of alluvial plains lies out of the protected area.
In WC, the relation between NFWV and geomorphological attributes such as altitude, slope and aspect was investigated as well (Demková and Lipský, 2015). Unfortunately, it cannot be compared with $\mathrm{KH}$ because of the flat relief with minimal altitude.

Landscape structure affects ecological processes (McGarigal et al., 2002). In this study, landscape structure is more heterogeneous in the WC study area than in $\mathrm{KH}$. It seems also to be less fragmented in WC although the mean patch size shows higher values in $\mathrm{KH}$. Lower patch density in $\mathrm{KH}$ in comparison with $\mathrm{WC}$, causes a higher index of mean nearest neighbour distance (Tab. 3). This index represents a simple expression of the degree of isolation among features of the same class. It does not take into account their size and counts only distances between two features (BotequilhaLeităo et al., 2006). Nevertheless, both metrics point to the low density of smaller vegetation features in the $\mathrm{KH}$ study area, which plays an important role for optimal functioning of the landscape, its ecological stability and landscape character as well. On the other hand, the relative length indicates a higher connectivity of linear vegetation in $\mathrm{KH}$. Skaloš and Engstová (2010) also compared patch density of NFWV and the relative length of tree alleys between two different study areas and concluded that the lowland study site had higher values of both metrics (relative length of tree alleys $1.8 \mathrm{~km} / \mathrm{km}^{2}$; patch density $86 \mathrm{No} / \mathrm{km}^{2}$ ) than the upland study site (relative length of tree alleys $0.5 \mathrm{~km} / \mathrm{km}^{2}$; patch density $11 \mathrm{No} / \mathrm{km}^{2}$ ). In comparison, however, NFWV in their study also comprises NFWV inside the village. Nevertheless, patch density in the lowland study site is markedly higher in their study than in ours, probably due to purposeful planting activities intended to increase biodiversity (Skaloš and Engstová, 2010).

A classification of NFWV according to prevailing woody plants (trees and shrubs), shape (linear, point and patch) and spatial criteria was also used by Plieninger et al. (2012). They distinguished eight classes of NFWV based on all three attributes combined. By contrast, many studies are only concerned with tree vegetation - scattered trees, isolated trees or trees outside forests (Bellefontaine et al., 2002; Levin et al., 2009; Manning et al., 2009; DeMars et al., 2010). Other studies concentrate on linear elements such as hedgerows (Burel, 1992; Barr and Gillespie, 2000; McCollin et al., 2000; Sklenička et al., 2009; Sánchez et al., 2010). Skaloš and Engstová (2010) and Skaloš et al. (2015) included not only scattered woody vegetation in the open landscapes, but also settlement vegetation in their research projects.

To determine the NFWV, the method of manual digitalisation of aerial photographs was applied, which is very laborious on the one hand but precise as it enables one to identify individual tree crowns. The same method was used by several other authors (Kleinn, 2000; Plieninger et al., 2012; Skaloš et al., 2015, etc.). Even Brown and Fisher (2009) concluded that manual digitisation is the most reliable method of mapping trees outside forests, although it is very time-consuming. In both of our study sites, aerial photo interpretation was verified during the field mapping in order to collect data about the condition of NFWV.

The two study areas, which were chosen to compare the current state of NFWV, have been recently investigated in terms of spatiotemporal changes of NFWV (Demková, Lipský, 2012, 2015). Although they represent just two landscape types - intensively farmed lowland and extensively 
used forest-agricultural upland - they provide a sufficient amount of data for testing the hypothesis. A comparison of the two contrasting types of study sites from the viewpoint of NFWV was also published by Skaloš and Engstová (2010) and Plieninger (2012). Both of these studies, however, present long-term changes in rates and distribution of NFWV, not a comparison of the current state from different perspectives. In this context, it will be beneficial to include in the research more localities of the same landscape type across the country, or more distinct landscape types to compare and verify the findings. Another challenge will be to apply additional methods of delineating NFWV (i.e. the official classification according to the Land Cadastre) and not only delineation based on spatial criteria.

\section{Conclusions}

Comparing two different study areas, we found that the proportion of NFWV in the lowland study site is lower than in the upland study site. Lowland NFWV is more gapped, isolated and its distribution is greatly unbalanced. Only linear vegetation shows a similar density in comparison with the upland area. Among habitat types, agrarian balks (especially stone balks), and erosive depressions were identified as typical for the upland study area, while in the lowland area NFWV connected with designed landscapes and monuments is very common. The differences between the study sites result from distinct natural conditions that influenced the different historical development of land use. The results also show a significant relation of NFWV to land cover types (especially to extensively farmed land cover types), partially to soil types, and to potential natural vegetation. More study sites are necessary, however, to verify these results in future research.

\section{Acknowledgements}

This research was supported by PRVOUK at the Faculty of Sciences of Charles University in Prague and by VUKOZIP-00027073 at the Silva Tarouca Research Institute for Landscape and Ornamental Gardening in Průhonice. The authors thank the reviewers and RNDr. Tomáš Uxa for their helpful comments.

\section{References:}

BARR, C. J., GILLESPIE, M. K. (2000): Estimating hedgerow length and pattern characteristics in Great Britain using Countryside Survey data. Journal of Environmental Management, 60: 23-32.

BAUDRY, J., BUNCE， R. G. H., BUREL， F. (2000): Hedgerows: An international perspective on their origin, function and management. Journal of Environmental Management, 60: 7-22.

BELLEFONTAINE, R., PETIT, S., PAIN-ORCET, M., DELEPORTE, P., BERTAULT, J. G. (2002): Trees outside forests: Towards a better awareness. FAO Conservation Guide 35

BÉLOUARD, T., COULON, F. (2002): Trees outside forests: France. In: Bellefontaine, R., Petit, S., Pain-Orcet, M., Deleporte, P., Bertault, J. G.: Trees outside forests: Towards a better awareness. FAO Conservation Guide, 35: 148-155.

BIČÍK, I., JELEČEK, L., ŠTĚPÁNEK, V. (2001): Land-use changes and their social driving forces in Czechia in the $19^{\text {th }}$ and $20^{\text {th }}$ centuries. Land Use Policy, 18: 65-73.
BOFFA, J. M. (2000): West African agroforestry parklands: keys to conservation and sustainable management. Unasylva 200, 51: 11-17.

BOTEQUILHA-LEITĂO, A., MILLER, J., AHERN, J., McGARIGAL, K. (2006): Measuring Landscapes: A Planner's Handbook. Washington, Island Press.

BROWN, N., FISHER, R. (2009): Trees outside woods. Woodland Trust, Grantham.

BUREL, F. (1992): Effect of landscape structure and dynamics on species diversity of hedgerow networks. Landscape Ecology, 6: 161-174.

BUREL, F., BAUDRY, J. (1990): Structural dynamics of a hedgerow network landscape in Brittany, France. Landscape Ecology, 4: 197-204.

BULÍŘ, P., ŠKORPÍK, M. (1987): Rozptýlená zelen v krajině. Aktuality výzkumného a šlechtitelského ústavu okrasného zahradnictví v Průhonicích, O. P. Sempra, Praha.

CHANDLER, K. R., CHAPPELL, N. A. (2008): Influence of individual oak (Quercus robur) trees on saturated hydraulic conductivity. Forest Ecology and Management, 256: $1222-1229$.

DeMARS， C. A., ROSENBERG，D. K., FONTAINE， J. B. (2010): Multi-scale factors affecting bird use of isolated remnants oak trees in agro-ecosystems. Biological Conservation, 143: 1485-1492.

DEMKOVÁ, K. (2011): The landscape character of the crofts Vrbovce and Chvojnica (southern part of White Carpathians in Slovakia). AUC Geographica, 46: 45-54.

DEMKOVÁ, K., LIPSKÝ, Z. (2012): Rozptýlená zeleň v krajině Novodvorska a Žehušicka. Acta Pruhoniciana, 101: 51-59.

DEMKOVÁ, K., LIPSKÝ, Z. (2013): Changes in the extent of non-forest woody vegetation in the Novodvorsko and Žehušicko Region (Central Bohemia, Czech Republic). AUC Geographica, 48: 5-13.

DEMKOVÁ, K., LIPSKÝ, Z. (2015): Změny nelesní dřevinné vegetace v jihozápadní části Bílých Karpat v letech 1949-2011. Geografie - Sborník ČGS, 120: 64-83.

DIVIAKOVÁ, A. (2010): Nelesná drevinová vegetácia a hodnotenie jej prírodochrannej, biotickej akrajinnoekologickej významnosti (modelové územie kataster obce Žibritov, Štiavnické vrchy).Geographia Cassoviensis, IV: 48-52.

EDITORIAL (2000): Trees outside forests. Unasylva 200, 51: 2.

ELDRIDGE， D. J., FREUDENBERGER, D. (2005): Ecosystem wicks: Woodland trees enhance water infiltration in a fragmented agricultural landscape in eastern Australia. Austral Ecology, 30: 336-347.

ERNOULT, A., ALARD, D. (2011): Species richness of hedgerow habitats in changing agricultural landscapes: are alfa and gama diversity shaped by the same factors? Landscape Ecology, 26: 683-696.

ESRI Inc. (2010): ArcMap, version 10.0. Available at: http:// www.esri.com

FAO (2001): Trees outside the forest: Towards rural and urban integrated resources management. Contribution to the forest resources assessment 2000 report. FAO Forest Conservation, Research and Education Service, Rome. 
FISCHER, J., LINDENMAYER, D. B. (2002): Small patches can be valuable for biodiversity conservation: Two case studies on birds in southeastern Australia. Biological Conservation,106: 129-136.

FISCHER, J., STOTT, J., LAW, B. S. (2010): The disproportionate value of scattered trees. Biological Conservation, 143: 1564-1567.

GILL, S. E., HANDLEY, J. F., ENNOS, A. R., PAULEIT, S. (2007): Adapting cities for climate change: The role of the green infrastructure. Built Environment, 33: 115-133.

HARVEY, C. A., HABER, W. A. (1999): Remnant trees and the conservation of biodiversity in Costa Rican pastures. Agroforestry Systems, 44: 37-68.

HIDALGO, D. M., KLEINN, C. (2002): Trees outside forests: Costa Rica. In: Bellefontaine, R., Petit, S., Pain-Orcet, M., Deleporte, P., Bertault, J. G.: Trees outside forests: Towards a better awareness. FAO Conservation Guide, 35: 141-147.

HUNZIKER, M. (1995): The spontaneous reafforestation in abandoned agricultural lands: perception and aesthetic assessment by locals and tourists. Landscape and Urban Planning, 31: 399-410.

IUSS Working Group WRB (2006): World reference base for soil resources 2006. 2nd edition. World Soil Resources Reports No. 103, FAO, Rome.

KLEINN, C. (2000): On large-area inventory and assessment of trees outside forests. Unasylva 200, 51: 3-10.

KOLAŘÍK, J. et al. (2003): Péče o dřeviny rostoucí mimo les - I. Vlašim, ČSOP.

KRISTENSEN, S. P., CASPERSEN, O. H. (2002): Analysis of changes in a shelterbelt network landscape in central Jutland, Denmark. Journal of Environmental Management, 66: 171-183.

KÜMMERLE, T., RADELOFF, V. C., PERZANOWSKI, K., HOSTERT, P. (2006): Cross-border comparison of land cover and landscape pattern in Eastern Europe using a hybrid classification technique. Remote Sensing of Environment, 103: 449-464.

LANG, S., TIEDE, D. (2003): vLATE Extension für ArcGIS - vektorbasiertes Tool zur quantitativen Landschaftsstrukturanalyse. ESRI Anwenderkonferenz, Innsbruck.

LIPSKÝ, Z., DEMKOVÁ, K., SKALOŠ, J., KUKLA, P. (2011): The influence of natural conditions on changes in landscape use: a case study of the Lower Podoubraví region (Czech Republic). Ekológia (Bratislava), 30: 239-256.

LEVIN, N., McAlPINE, C., PHINN, S., PRICE, B., PULLAR, D., KAVANAGH, R. P., LAW, B. S. (2009): Mapping forest patches and scattered trees from SPOT images and testing their ecological importace for woodlands birds in a fragmented agricultural landscape. International Journal of Remote Sensing, 30: 3147-3169.

MAGLOCKÝ, Š. (2002): Potential natural vegetation. In: Miklós, L., Hrnčiarová, T. [eds.]: Atlas of landscape in the Slovak Republic. MŽP SR, Bratislava, SAŽP, Banská Bystrica.

MACHOVEC, J. (1994): Rozptýlená zeleň v krajině. Vysoká škola zemědělská v Brně, Brno, UKE.
MALLINIS,G.,EMMANOLOUDIS,D., GIANNAKOPOULOS, V., MARIS, F., KOUTSIAS, N. (2011): Mapping and interpreting historical land cover/land use changes in a Natura 2000 site using earth observational data: the case of Nestos delta, Greece. Applied Geography, 31: 312-320.

MANNING, A. D., FISCHER, J., LINDENMAYER, D. B. (2006): Scattered trees are keystone structures implication for conservation. Biological Conservation, 132: 311-321.

MANNING, A. D., GIBBONS, P., LINDENMAYER, D. B. (2009): Scattered trees: a complementary strategy for facilitating adaptive responses to climate change in modified landscapes? Journal of Applied Ecology, 46: 915-919.

MAREČEK, J. (2005): Krajinářská architektura venkovských sídel Praha, ČZU.

McCOLLIN, D., JACKSON, J. I., BUNCE, R. G. H., BARR, C. J., STUART, R. (2000): Hedgerows as habitat for woodland plants. Journal of Environmental Management, 60: 77-99.

McDONALD, D., CRABTREE, J. R., WIESENGER, D., DAX, T., STAMOU, N., FLEURY, P., GUTIERREZLAZPITA, J., GIBTON, A. (2000): Agricultural abandonment in mountain areas of Europe: environmental consequences and policy response. Journal of Environmental Management, 59: 47-69.

McGARIGAL, K., MARKS, B. J., HOLMES, C., ENE, E. (2002): Fragstats 3.3: Spatial Pattern Analysis Program for Quantifying Landscape Structure, [online] [cit. 10.11.2014]. Available at: http://www.umass.edu/ landeco/research/fragstats/downloads/fragstats downloads.html

MOJSEJ, M., PETROVIČ, F. (2013): Land use changes of historical structures in the agricultural landscape at the local level - Hriňová case study. Ekológia Bratislava, 32: $1-12$.

MOLDAN, B. et al. (1990): Environment of the Czech Republic: translation of the "Blue book". Brno, Ekocentrum.

NEUHÄUSLOVÁ, Z. [ed.] (1998): Map of potential natural vegetation of the Czech Republic. Praha, Academia.

PELLANTOVÁ, J. et al. (1994): Metodika mapování krajiny. Praha, MŽP.

PLIENINGER, T., PULIDO, F. J., KONOLD, W. (2003): Effects of land-use history on size structure of holm oak stands in Spanish dehesas: implications for conservation and restoration. Environmental Conservation, 30: 61-70.

PLIENINGER, T., HÖCHTL, F., SPEK, T. (2006): Traditional land-use and nature conservation in European rural landscape. Environmental Science \& Policy, 9: 317-321.

PLIENINGER, T. (2012): Monitoring directions and rates of change in trees outside forests through multitemporal analysis of map sequences. Applied Geography, 32: 566-576.

PLIENINGER, T., SCHLEYER, C., MANTEL, M., HOSTERT, P. (2012): Is there a forest transition outside forests? Trajectories of farm trees and effects on ecosystem services in an agricultural landscape in Eastern Germany. Land Use Policy, 29: 233-243. 
REMPEL， R. S., KAUKINEN, D., CARR, A. P. (2012): Patch Analyst and Patch Grid [online] [cit. 10.11.2014]. OntarioMinistry of Natural Resources. Centre for Northern Forest Ecosystem Research, ThunderBay, Ontario Available at: http://www.cnfer.on.ca/SEP/ patchanalyst/

RYSZKOWSKI L., KEDZIORA A. (2007): Modification of water flows and nitrogen fluxes by shelterbelts. Ecological Engineering, 29: 388-400.

SÁNCHEZ, I. A., LASSALETTA, L., MCCOLLIN, D., BUNCE, R. B. H. (2010): The effect of hedgerow loss on microclimate in the Mediterranean region: an investigation in Central Spain. Agroforestry Systems, 78: $13-25$.

SCHAMA, S. (1995): Landscape and Memory. New York, A.A Knopf.

SCHNELL, S. (2015): Integrating trees outside forests into national forest inventories. Doctoral thesis, Swedish University of Agricultural Sciences.

SKALOŠ, J., ENGSTOVÁ, B. (2010): Methodology for mapping non-forest wood elements using historic cadastral maps and aerial photographs as a basis for management. Journal of Environmental Management, 91: 831-843.

SKALOŠ, J., WEBER, M., LIPSKÝ, Z., TRPÁKOVÁ, I., ŠANTRŮČKOVÁ, M., UHLÍŘOVÁ, L., KUKLA, P. (2011): Using old military survey maps and orthophotograph maps to analyse long-term land cover changes. Case study (Czech Republic). Applied Geography, 31: 426-438.
SKALOŠ, J., NOVOTNÝ, M., WOITSCH, J., ZACHAROVÁ, J., BERCHOVÁ, K., SVOBODA, M. et al. (2015): What are the transitions of woodlands at the landscape level? Change trajectories of forest, non-forest and reclamation woody vegetation elements in a mining landscape in Northwestern Czech Republic. Applied Geography, 58: 206-216.

SKLENIČKA， P., MOLNÁROVÁ, K., BRABEC, E., KUMBLE, P., PITTNEROVÁ, B., PIXOVÁ, K., ŠÁLEK, M. (2009): Remnants of medieval field patterns in the Czech Republic: Analysis of driving forces behind their disappearance with special attention to the role of hedgerows. Agriculture, Ecosystems and Environment, 129: 465-473.

SLÁVIKOVÁ, D. (1984): Význam lesa a rozptýlenej zelene pre tvorbu krajiny. Vedecké a pedagogické aktuality 3. Zvolen, Vysoká škola lesnícka a drevárska.

SLÁVIKOVÁ, D. (1987): Ochrana rozptýlenej zelene v krajine. Metodicko-námetová příručka č. 9. Bratislava, UV Slovenského zväzu ochrancov prírody a krajiny.

STATSOFT Inc. (2009): STATISTICA (data analysis software system), version 9.0. Available at: http://www.statsoft. com

SUPUKA, J., SCHLAMPOVÁ, T., JANCURA, P. (1999): Krajinárska tvorba. Zvolen, Technická univerzita.

ŠPULEROVÁ, J. (2006): Funkcie nelesnej drevinovej vegetácie v krajine. Životné prostredie, 40: 37-40.

VANÍČEK, V. (1985): Sociologický přístup k řešení krajinných agrostruktur. Sborník referátů (pp. 3-7). Pardubice, DT CSVTS.

\section{Please cite this article as:}

DEMKOVÁ, K., LIPSKÝ, Z. (2017): Comparison of the current state of non-forest woody vegetation in two contrasted case study areas in Central Europe. Moravian Geographical Reports, 25(1): 24-33. Doi: 10.1515/mgr-2017-0003. 